\title{
Influence of Preharvest and Postharvest Applications of Glycine Betaine on Fruit Quality Attributes and Storage Disorders of 'Lapins' and 'Regina' Cherries
}

\author{
Meng Li and Huanhuan Zhi \\ College of Food and Bioengineering, Zhengzhou University of Light \\ Industry, Zhengzhou, Henan 450002, China
}

\author{
Yu Dong ${ }^{1}$ \\ Department of Horticulture, Oregon State University, Mid-Columbia \\ Agricultural Research and Extension Center, 3005 Experiment Station \\ Drive, Hood River, OR 97031
}

Additional index words. glycine betaine, preharvest, postharvest, Prunus avium, quality, storage disorder

\begin{abstract}
This study aimed to evaluate whether preharvest or postharvest application of glycine betaine (GB) has the potential to improve fruit quality [fruit firmness (FF), size, skin color, soluble solids content (SSC), and titratable acidity (TA)] and susceptibility to storage disorders (peduncle browning, pitting, and decay) in 'Lapins' or 'Regina' sweet cherries, and to determine whether factors such as application frequency or timing impacted the efficacy of GB spraying. Adding 2 or $4 \mathrm{~g} \cdot \mathrm{L}^{-1} \mathrm{~GB}$ to hydro-cooling water $\left(0^{\circ} \mathrm{C}\right)$ as postharvest treatment did not affect fruit size, skin color, SSC, TA, peduncle browning, or pitting development; however, it did result in fruit softening and a low incidence of decay. GB applied preharvest at 2 or $4 \mathrm{~g} \cdot \mathrm{L}^{-1}$ once at 1 week before harvest (1WBH) was more effective for retaining FF and less peduncle browning and pitting compared with postharvest treatment. Increasing the preharvest GB application frequency from one time (1WBH or pit hardening) to three times (pit hardening, straw color, and 1WBH) enhanced FF and TA levels and resulted in lower pitting. The reduction in fruit size was observed for 'Regina', but not for 'Lapins'. Changes in the contents of phosphorous $(\mathrm{P})$, potassium $(\mathrm{K})$, and magnesium $(\mathrm{Mg})$ were unaffected by $\mathrm{GB}$ at harvest, whereas three GB sprays increased the total nitrogen $(N)$ content. Compared with 'Lapins', 'Regina' allowed more calcium (Ca) uptake by GB and ultimately had firmer flesh. In conclusion, three preharvest applications of $4 \mathrm{~g} \cdot \mathrm{L}^{-1} \mathrm{~GB}$ showed great potential to improve quality attributes, to reduce the susceptibility to storage disorders, and to increase the Ca content of 'Regina' cherries.
\end{abstract}

Sweet cherry is a highly perishable fruit with a short storage life. Fruit firmness (FF) is an important quality trait that has an impact on storage potential, disorder resistance, and decay development (Kappel et al., 1996). Poor appearance of soft fruit, such as dull skin color, surface pitting, and peduncle browning after storage or shipping, negatively impacts consumer purchase decisions

Received for publication 1 May 2019. Accepted for publication 7 June 2019.

Mention of a trademark, proprietary product, or vendor does not constitute a guarantee or warranty of the product by Oregon State University and does not imply its approval to the exclusion of other products or vendors that also may be suitable.

This research was supported by the Columbia Gorge Fruit Growers Commission, Oregon Sweet Cherry Commission, and the Washington Tree Fruit Research Commission.

${ }^{1}$ Corresponding author. E-mail: dongyu@oregonstate. edu.
(Turner et al., 2005; Zheng et al., 2016). The causes of fruit softening are largely attributed to improper preharvest treatment, delayed harvest date, calcium deficiency, and relatively high storage/shipping temperatures (Crisosto et al., 1993; Fils-Lycaon and Buret, 1990; Luo et al., 2014; Wang et al., 2014). Additionally, high activity of cell wallmodifying enzymes such as polygalacturonase, pectate lyase, and $\beta$-D-galactosidase are responsible for fruit softening (Zhi and Dong, 2018). Therefore, developing strategies to maintain high-quality attributes, especially FF, during development or the storage period will improve the quality of fruit delivered to high-value export markets.

Preharvest and postharvest applications of plant growth regulators have been proven to slow the deterioration of cherry quality (Correia et al., 2017; Valero et al., 2011; Zhang and Whiting, 2013). Glycine betaine (GB; $N, N, N$-trimethylglycine), which is a natural osmoregulator derived from sugar beet molasses, has a crucial role in preventing fruit from chilling injury, oxidative stress, and pathogen growth (Liu et al., 2011; Ragab et al., 2015; Razavi et al., 2018; Shan et al., 2015, 2016). In the Pacific Northwest region of the United States, GB sprays at 2 or 4 weeks before the harvest date slightly reduced rain-induced cracking in 'Sweetheart' cherries, but statistical differences were not detected in the sugar accumulation or FF (Hansen, 2010). During the storage period, GB-treated cherry fruits displayed significantly less pitting compared with untreated fruit (Hansen, 2010). The response of fruit to GB depends on the cultivar, whether treatment occurs preharvest or postharvest, application concentration, frequency, and timing (Ragab et al., 2015; Rodríguez-Zapata et al., 2015). Therefore, a new strategy for the commercial use of GB for sweet cherry was investigated.

The first objective of this study was to evaluate the effect of preharvest or postharvest application of GB at 2 or $4 \mathrm{~g} \cdot \mathrm{L}^{-1}$ on fruit quality attributes [i.e., FF, fruit size, skin color, soluble solids content (SSC), and titratable acid (TA)] and resistance to disorders (i.e., peduncle browning, pitting, and decay) of two major late-maturing cultivars, Lapins and Regina, grown in Oregon's MidColumbia region during storage at $0{ }^{\circ} \mathrm{C}$ for 4 weeks. The second objective was to determine if application frequency and timing affected the efficacy of preharvest GB spraying. The goal was to provide the sweet cherry grower with useful information regarding applying GB to these late-maturing sweet cherry cultivars.

\section{Materials and Methods}

Plant material. 'Lapins' and 'Regina' trees were selected from the orchard of the Mid-Columbia Agricultural Research and Extension Center in Hood River, OR (lat. 45.71, ${ }^{\circ} \mathrm{N}$, long. $121.51^{\circ} \mathrm{W}$, elevation $150 \mathrm{~m}$; average annual rainfall $\approx 350 \mathrm{~mm}$ ). 'Lapins' trees were 19 years old and on Mazzard rootstock. The spacing was $4.27 \mathrm{~m}$ (between trees in a row) $\times 4.88 \mathrm{~m}$ (between rows). 'Regina' trees were 17 years old and on Gisela 6 rootstock. The spacing was $3.05 \mathrm{~m}$ (between trees in a row) $\times 5.49 \mathrm{~m}$ (between rows). Irrigation was performed using a microsprinkler irrigation system between each tree in the row. All trees were maintained with standard fertilizer, herbicides, and pesticides. The meteorological data during the 2016 to 2018 growing seasons are summarized in Supplemental Table 1.

Glycine betaine ( $>96 \%$ glycine betaine; Bluestim; Verdera Oy, Espoo, Finland) was supplemented with $1 \mathrm{~g} \cdot \mathrm{L}^{-1}$ nonionic surfactant (Silwet L-77; Helena Chemical Co., Collierville, TN) and applied using a $\mathrm{CO}_{2}$ pressurized hand sprayer (Model D Less Boom; Bellspray Inc., Opelousas, LA) to achieve complete coverage of whole canopies. Study trees were sprayed when the outdoor temperature was less than $27^{\circ} \mathrm{C}$; application was avoided before rainfall. Fruit 
were harvested $1 \mathrm{~d}$ before the commercial harvest date and then packed in commercial polyethylene bags $(1 \mathrm{~kg})$ with a $2 \%$ perforation ration. For Expts. 1 and 2 in 2016, 2 and $4 \mathrm{~g} \cdot \mathrm{L}^{-1} \mathrm{~GB}$ were applied to hydro-cooling water at $0{ }^{\circ} \mathrm{C}$ for 'Lapins' or 'Regina' cherries or sprayed 1 week before harvest (1WBH) for 'Lapins' trees to evaluate the effects of preharvest and postharvest application of $\mathrm{GB}$ on fruit response during storage. After 4 weeks of storage at $0{ }^{\circ} \mathrm{C}$, postharvest application of GB resulted in a loss of FF, but not in preharvest treatment. Additionally, preharvest application had additional benefits for reducing peduncle browning and pitting development. Therefore, preharvest application frequency and timing were investigated in Expts. 3 and 4.

Expt. 1. In 2016, 'Lapins' and 'Regina' cherries free of any visible damage or fungal infection and of uniform size were picked on 22 June. Fruit of each cultivar with intact peduncles were divided into three treatments $\times$ three replicates $\times$ one box per replicate $(=9$ boxes of $10 \mathrm{~kg}$ per box). Fruit from each treatment were soaked for $10 \mathrm{~min}$ in $12 \mathrm{~L}$ of one of the following solutions: hydro-cooling water at $0{ }^{\circ} \mathrm{C}$ (control); $2 \mathrm{~g} \cdot \mathrm{L}^{-1}$ (GB hydrocooling water with $2 \mathrm{~g} \cdot \mathrm{L}^{-1} \mathrm{~GB}$ ); or $4 \mathrm{~g} \cdot \mathrm{L}^{-1} \mathrm{~GB}$ (hydro-cooling water with $4 \mathrm{~g} \cdot \mathrm{L}^{-1} \mathrm{~GB}$ ). After treatment, fruit were air-dried with a fan for $15 \mathrm{~min}$ and then packed and stored at $0{ }^{\circ} \mathrm{C}$ for 4 weeks. After 2 or 4 weeks of storage, a sample of 480 fruit from each treatment was transferred to $20^{\circ} \mathrm{C}$ and analyzed after $4 \mathrm{~h}$ of temperature equilibration. Fruit with three replicates with 60 fruit per replicate were evaluated for fruit quality attributes (i.e., FF, fruit size, skin color, SSC, and TA). Three replicates with 100 fruit per replicate were evaluated for storage disorders (i.e., peduncle browning, pitting, and decay).

Expt. 2. In 2016, 'Lapins' trees were randomly selected and divided into three treatments with three replicates of two trees each and then treated with $\mathrm{H}_{2} \mathrm{O}$ with $1 \mathrm{~g} \cdot \mathrm{L}^{-1}$ nonionic surfactant (control), $2 \mathrm{~g} \cdot \mathrm{L}^{-1} \mathrm{~GB}$, or 4 g. $\mathrm{L}^{-1} \mathrm{~GB}$. All treatments were applied once on 15 June, $1 \mathrm{WBH}$. Fruit were harvested on 22 June an then loaded into polyethylene bags and stored at $0{ }^{\circ} \mathrm{C}$ for up to 4 weeks. Fruit quality attributes and storage disorders were analyzed as described for Expt. 1.

Expt. 3. In 2017, 'Lapins' or 'Regina' trees were randomly selected and divided into three treatments with three replicates of two trees each and then treated with $\mathrm{H}_{2} \mathrm{O}$ with $1 \mathrm{~g} \cdot \mathrm{L}^{-1}$ nonionic surfactant (control), $2 \mathrm{~g} \cdot \mathrm{L}^{-1}$ $\mathrm{GB}$, or $4 \mathrm{~g} \cdot \mathrm{L}^{-1} \mathrm{~GB}$. All treatments were applied three times: at pit hardening (20 May for 'Lapins'; 23 May for 'Regina'); straw color ( 9 June for 'Lapins'; 12 June for 'Regina'); and 1WBH (5 July for 'Lapins'; 12 July for 'Regina'). Fruit quality attributes and storage disorders were analyzed as described for Expt. 1.

Expt. 4. In 2018, 'Lapins' or 'Regina' trees were randomly selected and divided into three treatments with three replicates of two trees each and then treated with $\mathrm{H}_{2} \mathrm{O}$ with $1 \mathrm{~g} \cdot \mathrm{L}^{-1}$ nonionic surfactant (control), $4 \mathrm{~g} \cdot \mathrm{L}^{-1}$
GB applied once at pit hardening), or $4 \mathrm{~g} \cdot \mathrm{L}^{-1}$ GB applied three times at pit hardening (18 May for 'Lapins'; 21 May for 'Regina'), straw color (9 June for 'Lapins'; 14 June for 'Regina'), and 1WBH (27 June for 'Lapins'; 2 July for 'Regina'). Fruit quality attributes and disorders were analyzed as described for Expt. 1. A fruit nutrients analysis was performed at harvest to investigate the impact of GB on the total nitrogen $(\mathrm{N})$, phosphorous $(\mathrm{P})$, magnesium $(\mathrm{Mg})$, potassium $(\mathrm{K})$, and calcium $(\mathrm{Ca})$ contents of the fruit.

Evaluations of fruit firmness, fruit size, skin color, soluble solids content, and titratable acidity. The FF of 60 fruit per replicate was determined nondestructively using a FirmTech-2 firmness instrument (BioWorks Inc., Stillwater, OK). Fruit size was expressed as the widest point of the fruit opposite the suture. Skin color was rated on a scale of 1 to 7, with 1 indicating blush, 2 indicating rose, 3 indicating ruby, 4 indicating crimson, 5 indicating currant, 6 indicating merlot, and 7 indicating mahogany, using the Pacific Northwest Dark Sweet Cherry Development Index Chart developed by Oregon State University. After determination, $100 \mathrm{~g}$ of cherries from 60 fruit per replicate were juiced for 3 min using a juicer (6001; Acme Juicer Manufacturing Co., Sierra Madre, CA) equipped with a uniform milk filter strip (Schwartz Manufacturing Co., Two Rivers, WI). The SSC was determined using a refractometer (PAL-1; Atago, Tokyo, Japan). The TA was determined by titrating $10 \mathrm{~mL}$ of juice plus $40 \mathrm{~mL}$ of distilled water to $\mathrm{pH} 8.1$ with $0.1 \mathrm{~N}$ of $\mathrm{NaOH}$ using a titrator (DL-15; Mettler-Toledo, Zurich, Switzerland) and expressed as the equivalent percentage of malic acid.

Evaluations of peduncle browning, pitting, and decay. Peduncle browning was evaluated after 2 and 4 weeks of storage and recorded as a percentage of 100 sample fruit peduncles showing browning of more than $30 \%$ of the entire surface (Clayton et al., 2003). Pitting was evaluated after evaluating the peduncle browning. Grading was standardized using a 4-point scale (Toivonen et al., 2004): 1, superficial pitting, pit diameter $1 \mathrm{~mm}$ or smaller, very shallow depression of the skin with diffuse edges; 2 , minimal pitting, pit diameter 1 to $2 \mathrm{~mm} ; 3$, moderate pitting, pit diameter 2 to $3 \mathrm{~mm}$, deeper and wider, with clearly distinct edges; and 4 , severe pitting, pit diameter $3 \mathrm{~mm}$ or larger, very deep, edges of pits sunken into pulp tissue. Pitting was calculated in each replicate as the total number of fruits in each of the four categories multiplied by the four factors $(1,2,3$, and 4$)$, and the total was divided by 100 and expressed as 1 to 4 . Decay was expressed as a percentage of 100 fruit samples showing any type of decay; however, the decay organisms were not identified.

Determination of fruit nutrients. Thirty fruit per replicate per treatment were collected for the nutrient analysis. Total $\mathrm{N}$ was determined using a combustion analyzer, and $\mathrm{P}, \mathrm{Mg}, \mathrm{K}$, and $\mathrm{Ca}$ were determined using a Thermo 6500 duo inductively coupled plasma spectrophotometer (Thermo and Fisher Scientific, Waltham, MA). Samples were washed, oven-dried at $65{ }^{\circ} \mathrm{C}$, and ground to pass through a $2-\mathrm{mm}$ sieve. After digesting in a microwave system (MARS Express CEM, Matthews, NC) by nitric acid and hydrogen peroxide, prepared samples were analyzed and data were expressed based on dry weight as $\mathrm{g} \cdot \mathrm{kg}^{-1}$.

Statistical analysis. Experiments were performed using a completely randomized design. One-way analysis of variance was performed to determine the significance of differences between means using Fisher's protected least significant difference (LSD) test $(P<0.05)$. Data were subjected to analysis using IBM SPSS Statistics (IBM Co. Armonk, NY).

\section{Results and Discussion}

Postharvest application of GB to 'Lapins' and 'Regina' cherries. Postharvest application of GB to fruit has been demonstrated to delay quality deterioration, to promote bioactive compound accumulation, and to enhance chilling tolerance (Razavi et al., 2018; Shan et al., 2015, 2016). However, in this study, 2 or $4 \mathrm{~g} \cdot \mathrm{L}^{-1} \mathrm{~GB}$ in hydro-cooling water applied postharvest did not affect fruit skin color, SSC, or TA of 'Lapins' or 'Regina' cherries, but these treatments markedly reduced FF during storage at $0{ }^{\circ} \mathrm{C}$ compared with control (Table 1). High FF is strongly preferred for sweet cherry so they are better able to withstand the handling, sorting, packing, storing, and transporting processes (Correia et al., 2017). Loss of FF directly impacts weight loss, off flavors, flesh browning, surface pitting, discoloration of the green stem, and fungal rotting (Kappel et al., 1996; Turner et al., 2005; Zheng et al., 2016). Although postharvest application of GB to 'Lapins' or 'Regina' cherries was shown to have an adverse effect on FF, GB-treated fruit had equal rates of peduncle browning and pitting relative to untreated fruit. Interestingly, a low incidence of decay was observed for GB-treated fruit, indicating that postharvest application of GB could enhance the tolerance of fruit against environmental stresses and senescence that might contribute to increased activity of antioxidant enzymes and bioactive compounds (Awad et al., 2015; Liu et al., 2011).

Preharvest application of GB on 'Lapins' cherries. Preharvest GB sprays have previously shown efficacy in alleviating the adverse drought stress and rain-induced cracking (Hansen, 2010; Lahdenperä, 2006). To identify the role of GB in fruit development, GB at 2 or 4 g. $\mathrm{L}^{-1}$ was sprayed on 'Lapins' trees at $1 \mathrm{WBH}$. Compared with the postharvest application results, spraying GB $1 \mathrm{WBH}$ did not affect FF, but it did increase resistance to peduncle browning and pitting development (Table 2). No effect of GB was observed on fruit size, skin color, or SSC accumulation. Although GB did not affect TA during the first 2 weeks of storage, significantly lower levels of TA were 
Table 1. Effect of 2016 postharvest application of 2 and $4 \mathrm{~g} \cdot \mathrm{L}^{-1}$ glycine betaine (GB) to hydro-cooling water $\left(0^{\circ} \mathrm{C}\right)$ on fruit quality attributes $(\mathrm{FF}$, fruit size, skin color, SSC, TA) and storage disorders (peduncle browning, pitting, and decay) of 'Lapins' and 'Regina' cherries after 2 or 4 weeks of storage at $0{ }^{\circ} \mathrm{C}$.

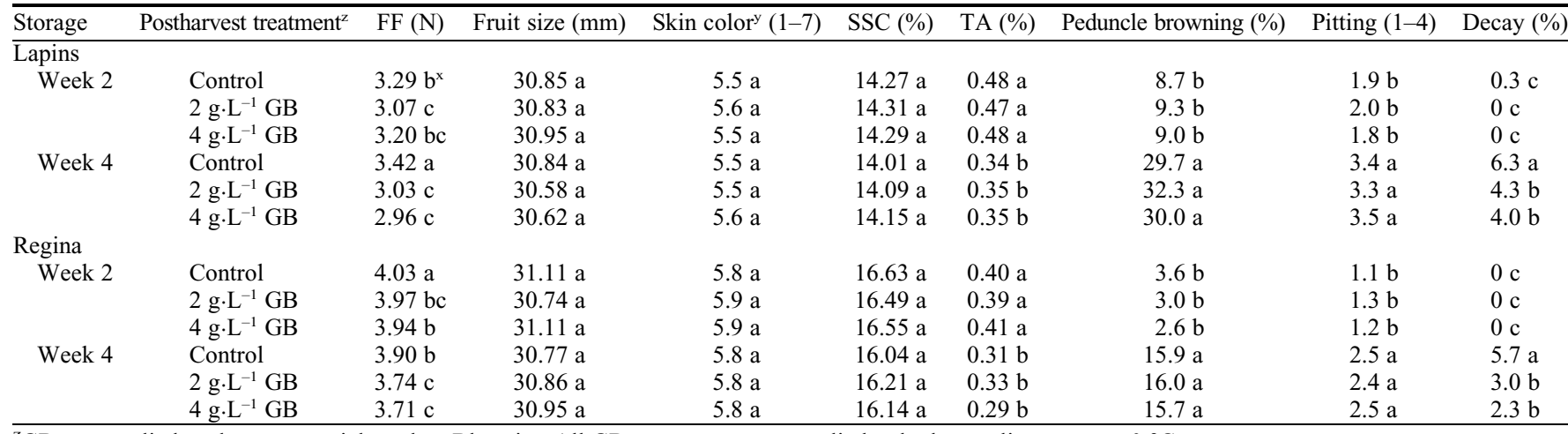

${ }^{\mathrm{z}} \mathrm{GB}$ was applied as the commercial product Bluestim. All GB treatments were applied to hydro-cooling water at $0{ }^{\circ} \mathrm{C}$.

${ }^{\mathrm{y}}$ Skin color was evaluated using the Pacific Northwest Dark Sweet Cherry Development Index Chart and a scale of 1 to 7 (blush to mahogany).

${ }^{\mathrm{x}}$ Means of each cultivar in the same column with different letters indicate significant differences according to Fisher's protected least significant difference test at $P<0.05$. Data are means of three replicates: $\mathrm{n}=60$ for FF, fruit size, skin color, SSC, and TA; $\mathrm{n}=100$ for peduncle browning, pitting, and decay.

$\mathrm{FF}=$ fruit firmness; $\mathrm{SSC}=$ soluble solids content; $\mathrm{TA}=$ titratable acidity.

Table 2. Effect of 2016 preharvest application of 2 or $4 \mathrm{~g} \cdot \mathrm{L}^{-1} \mathrm{~GB}$ at 1 week before harvest (1WBH) on fruit quality attributes and storage disorders of 'Lapins' cherries at harvest and after 2 or 4 weeks of storage at $0{ }^{\circ} \mathrm{C}$.

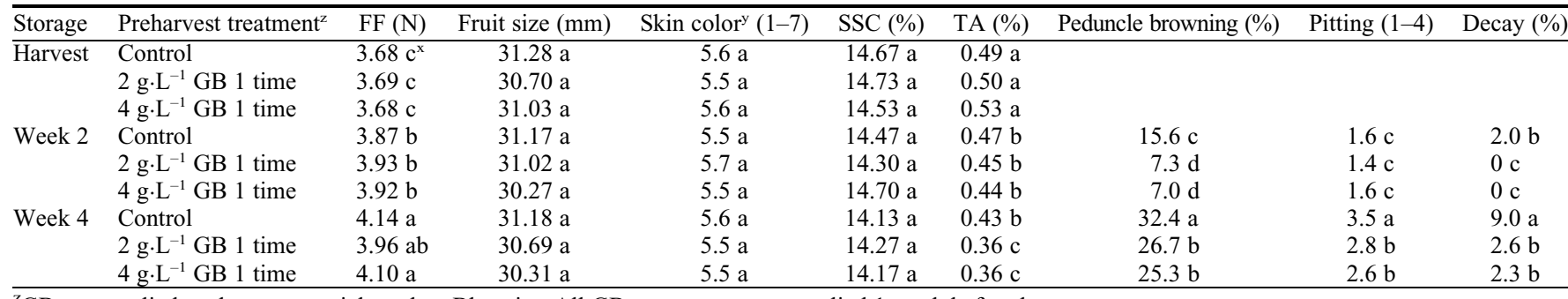

${ }^{\mathrm{z}} \mathrm{GB}$ was applied as the commercial product Bluestim. All GB treatments were applied 1 week before harvest.

${ }^{\mathrm{y}}$ Skin color was evaluated using the Pacific Northwest Dark Sweet Cherry Development Index Chart and a scale of 1 to 7 (blush to mahogany).

${ }^{\mathrm{x}} \mathrm{Means}$ of each cultivar in the same column with different letters indicate significant differences according to Fisher's protected least significant difference test at $P<0.05$. Data are means of three replicates: $\mathrm{n}=60$ for FF, fruit size, skin color, SSC, and TA; $\mathrm{n}=100$ for peduncle browning, pitting, and decay.

$\mathrm{FF}=$ fruit firmness; $\mathrm{SSC}=$ soluble solids content; $\mathrm{TA}=$ titratable acidity.

observed for GB-treated fruit after 4 weeks of storage. In addition, GB applied preharvest showed inhibition of decay that was similar to that for postharvest application. These results indicated that GB applied preharvest was more beneficial for reducing fruit susceptibility to storage disorders than postharvest application, perhaps due to the action of GB as a plant growth regulator of fruit development.

Effects of application frequency and timing of GB on 'Lapins' and 'Regina' cherries. To further confirm the effects of GB on fruit development, application frequency and timing were investigated. In 2017, three GB sprays of 2 and $4 \mathrm{~g} \cdot \mathrm{L}^{-1}$ significantly increased FF of 'Lapins' cherries compared with untreated fruit. For 'Regina' cherries, when GB was applied at $4 \mathrm{~g} \cdot \mathrm{L}^{-1}$, increased FF was observed, indicating that GB application at $4 \mathrm{~g} \cdot \mathrm{L}^{-1}$ was sufficient to improve FF of both cultivars (Table 3 ). In 2018, a single application of GB at $4 \mathrm{~g} \cdot \mathrm{L}^{-1}$ once at the pit hardening stage or three times at pit hardening, straw color, and $1 \mathrm{WBH}$ for 'Lapins' did not cause high FF at harvest; however, it slowed the reductions of FF after 4 weeks of storage (Table 4). For 'Regina', three applications of GB maintained high FF levels at harvest or during storage. Correia et al. (2019) reported that $1 \mathrm{~g} \cdot \mathrm{L}^{-1} \mathrm{~GB}$ applied at 30,49 , and $56 \mathrm{~d}$ after full bloom increased the FF of 'Skeena' cherries. Lahdenperä (2006) reported that two or three split applications of GB significantly reduced fruit cracking in 'Garnet' cherries. Furthermore, early split applications of GB at the late light green/start of straw color and straw/pink transition stages resulted in reduced fruit cracking compared to two applications of GB spray twice at the straw/pink transition and light red stages. This explained why reducing the GB frequency from three times to one time at the pit hardening stage had little to no effect on FF. Taken together, the 2016 to 2018 preharvest application results suggested that multiple and early applications of GB were an effective way of improving the FF of sweet cherry.

Developing strategies to increase fruit size is of great interest to growers. In this study, regardless of the application concentration, timing, or frequency, GB did not affect the fruit size of 'Lapins', as previously shown for 'Skeena' (Correia et al., 2019). GB did decrease the fruit size of 'Regina' when applied three times or once at pit hardening. Generally, the reduced fruit size may be due to excessive crop loading, deficit irrigation, dwarfing rootstocks, or improper thinning
(Edin et al., 1993; Neilsen et al., 2007; Whiting and Lang, 2004; Whiting and Ophardt, 2005). However, 'Regina' typically displays a poor fruit set in Oregon's MidColumbia region, and its light bearing results in relatively large fruit at harvest (Warner, 2013). Declines in the fruit size of 'Regina' may be due to the effects of GB on cell division or enlargement. There are three distinct growth stages during sweet cherry development (Coombe, 1976). Stage I is characterized by rapid enlargement beginning at full bloom; stage II is characterized by slowed pericarp development with endocarp hardening and embryo development; and stage III is characterized by rapid pericarp development before fruit ripening (Tukey, 1936). At the end of stage II, the pit hardening stage, a high rate of cell division that will determine the final cell number within the fruit nears completion (Tukey and Young, 1939). The 2017 to 2018 results assured that a single application of GB at pit hardening decreased the observed fruit size of 'Regina' cherries at harvest. However, it is unclear whether spraying GB after the pit hardening stage would alleviate or diminish the negative effects on fruit size.

Fruit skin color is a primary indicator of the reliable prediction of overall quality and 
Table 3. Effects of 2017 preharvest application of 2 or $4 \mathrm{~g} \cdot \mathrm{L}^{-1} \mathrm{~GB}$ three times at pit hardening, straw color, and 1 week before harvest (1WBH) on fruit quality attributes and storage disorders of 'Lapins' and 'Regina' cherries at harvest and after 2 or 4 weeks of storage at $0{ }^{\circ} \mathrm{C}$.

\begin{tabular}{|c|c|c|c|c|c|c|c|c|c|}
\hline Storage & Preharvest treatment ${ }^{2}$ & $\mathrm{FF}(\mathrm{N})$ & Fruit size $(\mathrm{mm})$ & Skin color $^{\mathrm{y}}(1-7)$ & SSC (\%) & TA $(\%)$ & Peduncle browning (\%) & Pitting (1-4) & Decay $(\%)$ \\
\hline \multirow[t]{3}{*}{ Harvest } & Control & $3.26 c^{x}$ & $28.59 \mathrm{a}$ & $5.8 \mathrm{a}$ & $0.59 \mathrm{a}$ & $17.00 \mathrm{a}$ & & & \\
\hline & 2 g. $\mathrm{L}^{-1}$ GB 3 times & $3.39 \mathrm{~b}$ & $27.88 \mathrm{a}$ & $5.5 \mathrm{a}$ & $0.57 \mathrm{a}$ & $16.23 \mathrm{~b}$ & & & \\
\hline & $4 \mathrm{~g} \cdot \mathrm{L}^{-1} \mathrm{~GB} 3$ times & $3.41 \mathrm{~b}$ & $26.89 \mathrm{a}$ & $5.7 \mathrm{a}$ & $0.56 \mathrm{a}$ & $16.47 \mathrm{~b}$ & & & \\
\hline \multirow{2}{*}{ Week 2} & $2 \mathrm{~g} \cdot \mathrm{L}^{-1} \mathrm{~GB} 3$ times & $3.55 \mathrm{a}$ & $28.33 \mathrm{a}$ & $5.6 \mathrm{a}$ & $0.47 \mathrm{~b}$ & $15.63 \mathrm{c}$ & $7.0 \mathrm{~d}$ & $1.2 \mathrm{~d}$ & $0 \mathrm{c}$ \\
\hline & $4 \mathrm{~g} \cdot \mathrm{L}^{-1} \mathrm{~GB} 3$ times & $3.68 \mathrm{a}$ & $28.17 \mathrm{a}$ & $5.8 \mathrm{a}$ & $0.46 \mathrm{~b}$ & $16.55 \mathrm{~b}$ & $4.3 \mathrm{e}$ & $1.3 \mathrm{~d}$ & $0 \mathrm{c}$ \\
\hline Week 4 & Control & $3.39 \mathrm{~b}$ & $29.06 \mathrm{a}$ & $5.7 \mathrm{a}$ & $0.55 \mathrm{a}$ & $16.57 \mathrm{~b}$ & $26.3 \mathrm{a}$ & $3.5 \mathrm{a}$ & $8.3 \mathrm{a}$ \\
\hline \multirow{3}{*}{ Harvest } & Control & $3.30 \mathrm{~d}$ & $28.80 \mathrm{a}$ & $6.4 \mathrm{a}$ & $0.50 \mathrm{~b}$ & $19.13 \mathrm{c}$ & & & \\
\hline & $2 \mathrm{~g} \cdot \mathrm{L}^{-1} \mathrm{~GB} 3$ times & $3.38 \mathrm{~cd}$ & $27.67 \mathrm{~b}$ & $6.3 \mathrm{a}$ & $0.56 \mathrm{a}$ & $19.53 \mathrm{bc}$ & & & \\
\hline & $4 \mathrm{~g} \cdot \mathrm{L}^{-1} \mathrm{~GB} 3$ times & $3.41 \mathrm{~cd}$ & $27.85 \mathrm{~b}$ & $6.4 \mathrm{a}$ & $0.59 \mathrm{a}$ & $20.17 \mathrm{a}$ & & & \\
\hline \multirow[t]{3}{*}{ Week 2} & Control & $3.47 \mathrm{c}$ & $28.80 \mathrm{a}$ & $6.4 \mathrm{a}$ & $0.45 \mathrm{c}$ & $19.17 \mathrm{c}$ & $2.0 \mathrm{~d}$ & $1.3 \mathrm{~b}$ & $0 \mathrm{c}$ \\
\hline & $2 \mathrm{~g} \cdot \mathrm{L}^{-1}$ GB 3 times & $3.34 \mathrm{~d}$ & $28.06 \mathrm{~b}$ & $6.4 \mathrm{a}$ & $0.50 \mathrm{~b}$ & $19.47 \mathrm{bc}$ & $1.7 \mathrm{~d}$ & $1.2 \mathrm{~b}$ & $0 \mathrm{c}$ \\
\hline & $4 \mathrm{~g} \cdot \mathrm{L}^{-1}$ GB 3 times & $3.59 \mathrm{~b}$ & $27.77 \mathrm{~b}$ & $6.4 \mathrm{a}$ & $0.53 \mathrm{~b}$ & $19.63 \mathrm{~b}$ & $1.3 \mathrm{~d}$ & $1.2 \mathrm{~b}$ & $0 \mathrm{c}$ \\
\hline
\end{tabular}

${ }^{\mathrm{z}} \mathrm{GB}$ was applied as the commercial product Bluestim. All GB treatments were applied when fruit were in the pit hardening stage (the end of stage II development), straw color stage (skin color transitioned from green to straw color), and $1 \mathrm{WBH}$.

${ }^{\mathrm{y}}$ Skin color was evaluated using the Pacific Northwest Dark Sweet Cherry Development Index Chart and a scale of 1 to 7 (blush to mahogany).

${ }^{x}$ Means of each cultivar in the same column with different letters indicate significant differences according to Fisher's protected least significant difference test at $P<0.05$. Data are means of three replicates: $\mathrm{n}=60$ for FF, fruit size, skin color, $\mathrm{SSC}$, and $\mathrm{TA} ; \mathrm{n}=100$ for peduncle browning, pitting, and decay.

$\mathrm{FF}=$ fruit firmness; $\mathrm{SSC}=$ soluble solids content; $\mathrm{TA}=$ titratable acidity.

Table 4. Effects of 2018 preharvest spray of GB at $4 \mathrm{~g} \cdot \mathrm{L}^{-1}$ applied 1 time (pit hardening) or 3 times (pit hardening, straw color, and 1 week before harvest) on fruit quality attributes and storage disorders of 'Lapins' and 'Regina' cherries at harvest and after 2 or 4 weeks of cold storage $0{ }^{\circ} \mathrm{C}$.

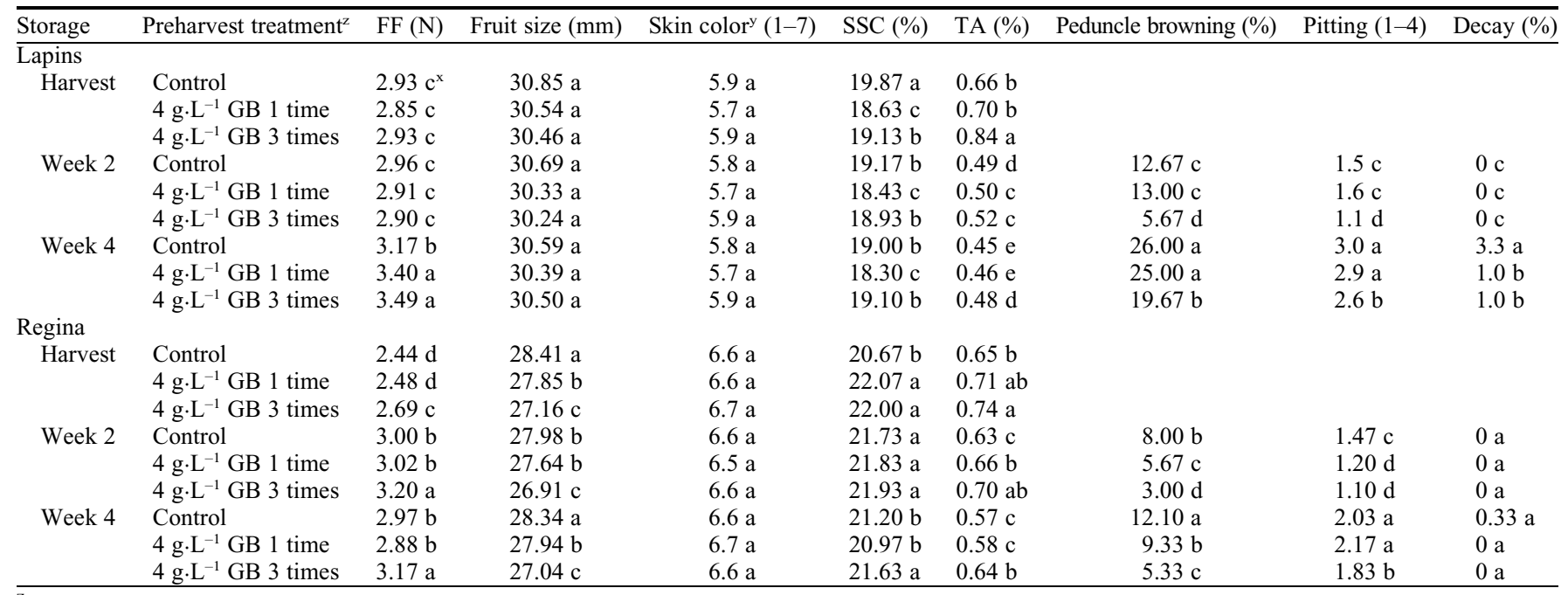

${ }^{\mathrm{z}} \mathrm{GB}$ was applied as the commercial product Bluestim. For one application, GB treatment was applied at the pit hardening stage (the end of stage II of development). For three application, GB treatment was applied at the pit hardening stage, straw color stage (skin color transitioned from green to straw color), and 1 week before harvest.

${ }^{y}$ Skin color was evaluated using the Pacific Northwest Dark Sweet Cherry Development Index Chart and a scale of 1 to 7 (blush to mahogany).

${ }^{x}$ Means of each cultivar in the same column with different letters indicate significant differences according to Fisher's protected least significant difference test at $P<0.05$. Data are means of 3 replicates: $\mathrm{n}=60$ for FF, fruit size, skin color, SSC, and TA; $\mathrm{n}=100$ for peduncle browning, pitting, and decay.

$\mathrm{FF}=$ fruit firmness; $\mathrm{SSC}=$ soluble solids content; TA $=$ titratable acidity

maturity of sweet cherry (Drake and Elfving, 2002; Ingalsbe et al., 1965; Serrano et al., 2009). Consumer purchase decisions regarding fresh cherry are greatly influenced by the darkening of skin color (Crisosto et al., 2003). GB sprays could result in a deeper red color for both 'Skeena' and 'Sweetheart' cherries (Correia et al., 2019). However, in this study, skin color of either cultivar was unaffected by GB (Tables 2-4). Therefore, it was difficult to definitively conclude the effects of GB on fruit coloring.
Ragab et al. (2015) reported that foliar application of 5 to $20 \mathrm{mmol} \cdot \mathrm{L}^{-1}$ of GB under deficit irrigation promoted high SSC levels in tomato fruit. However, the SSC accumulation and TA level of fruit in response to GB were inconsistent for 'Lapins'. For example, GB did not affect SSC, but it decreased the TA in 2017; in 2018, low levels of SSC and increased TA levels were observed with GB treatments. For 'Regina', GB had a positive effect on increasing the levels of SSC and TA, especially with three application of GB at $4 \mathrm{~g} \cdot \mathrm{L}^{-1} \mathrm{~GB}$. Correia et al. (2019) found that the total sugar levels of 'Skeena' and 'Sweetheart' cherries were not influenced by GB; the sum of the organic acids in 'Sweetheart' significantly increased with GB treatment, but this effect was not seen in 'Skeena'. Therefore, the responses of SSC and TA to GB in cherry might be cultivar-dependent.

Consumers prefer fresh sweet cherry with fewer physiological disorders, such as peduncle browning, flesh browning, surface pitting, bruising, and fungal diseases 
Table 5. Effects of 2018 preharvest spray of GB at $4 \mathrm{~g} \cdot \mathrm{L}^{-1}$ applied 1 time (pit hardening) or 3 times (pit hardening, straw color, and 1 week before harvest) on the contents of total nitrogen $(\mathrm{N})$, phosphorous $(\mathrm{P})$, magnesium $(\mathrm{Mg})$, potassium $(\mathrm{K})$, and calcium $(\mathrm{Ca})$ of 'Lapins' and 'Regina' at harvest.

\begin{tabular}{|c|c|c|c|c|c|}
\hline Preharvest treatment $^{z}$ & $\mathrm{~N}\left(\mathrm{~g} \cdot \mathrm{kg}^{-1}\right)$ & $\mathrm{P}\left(\mathrm{g} \cdot \mathrm{kg}^{-1}\right)$ & $\mathrm{K}\left(\mathrm{g} \cdot \mathrm{kg}^{-1}\right)$ & $\mathrm{Mg}\left(\mathrm{g} \cdot \mathrm{kg}^{-1}\right)$ & $\mathrm{Ca}\left(\mathrm{g} \cdot \mathrm{kg}^{-1}\right)$ \\
\hline \multicolumn{6}{|l|}{ Lapins } \\
\hline Control & $6.66 b^{y}$ & $1.17 \mathrm{a}$ & $10.47 \mathrm{a}$ & $0.51 \mathrm{a}$ & $0.50 \mathrm{a}$ \\
\hline $4 \mathrm{~g} \cdot \mathrm{L}^{-1} \mathrm{~GB} 1$ time & $5.93 \mathrm{~b}$ & $1.05 \mathrm{a}$ & $10.23 \mathrm{a}$ & $0.47 \mathrm{a}$ & $0.43 \mathrm{a}$ \\
\hline $4 \mathrm{~g} \cdot \mathrm{L}^{-1} \mathrm{~GB} 3$ times & $9.99 \mathrm{a}$ & $1.18 \mathrm{a}$ & $10.27 \mathrm{a}$ & $0.52 \mathrm{a}$ & $0.44 \mathrm{a}$ \\
\hline \multicolumn{6}{|l|}{ Regina } \\
\hline Control & $4.90 \mathrm{~b}$ & $1.18 \mathrm{a}$ & $9.50 \mathrm{a}$ & $0.44 \mathrm{a}$ & $0.57 \mathrm{~b}$ \\
\hline $4 \mathrm{~g} \cdot \mathrm{L}^{-1} \mathrm{~GB} 1$ time & $4.77 \mathrm{~b}$ & $1.19 \mathrm{a}$ & $8.63 \mathrm{a}$ & $0.48 \mathrm{a}$ & $0.77 \mathrm{a}$ \\
\hline $4 \mathrm{~g} \cdot \mathrm{L}^{-1} \mathrm{~GB} 3$ times & $6.80 \mathrm{a}$ & $1.18 \mathrm{a}$ & $9.53 \mathrm{a}$ & $0.49 \mathrm{a}$ & $0.73 \mathrm{a}$ \\
\hline
\end{tabular}

${ }^{\mathrm{z}} \mathrm{GB}$ was applied as the commercial product Bluestim. For one application, GB treatment was applied at the pit hardening stage (the end of stage II of development). For three applications, GB treatment was applied at the pit hardening stage, straw color stage (skin color transitioned from green to straw color), and 1 week before harvest.

${ }^{y}$ Means of each cultivar in the same column with different letters indicate significant differences according to Fisher's protected least significant difference (LSD) test at $P<0.05$. Data are means of 3 replicates: $\mathrm{n}=30$.

(Romano et al., 2006). The role of GB in controlling the development of storage disorders is not clear, although other works have shown that GB reduces the sensitivity of sweet cherry to cracking damage (Hansen, 2010; Lahdenperä, 2006). Notably, compared with three applications of $2 \mathrm{~g} \cdot \mathrm{L}^{-1} \mathrm{~GB}$ or a single application at pit hardening or $1 \mathrm{WBH}$, three applications of $\mathrm{GB}$ at $4 \mathrm{~g} \cdot \mathrm{L}^{-1}$ increased resistance to peduncle browning, pitting, and decay in both cultivars after 4 weeks of storage (Tables 2-4). Clearly, the concentration, frequency, and timing of the GB application affected the ability of 'Lapins' or 'Regina' cherries to resist disorder development.

Effect of $G B$ on fruit nutrients. In this study, the total N, P, K, Mg, and Ca of the fruit were examined at harvest. In both cultivars, a single application or three applications of GB at $4 \mathrm{~g} \cdot \mathrm{L}^{-1}$ did not affect the contents of $\mathrm{P}, \mathrm{K}$, and $\mathrm{Mg}$, but three applications of GB significantly increased the total N content (Table 5). Marschner (1995) reported that a higher $\mathrm{N}$ content in plants might result in greater nutrient uptake from the soil. Swarts et al. (2017) found that a preharvest application of $\mathrm{N}$ increased the $\mathrm{N}$ content in fruit, but it had a detrimental effect on FF. Moreover, a high rate of $\mathrm{N}$ applied to fruit (i.e., $42 \mathrm{mg} \cdot \mathrm{L}^{-1}$ ) reduced the fruit size and TA, whereas SSC and FF were unaffected (Neilsen et al., 2007). In our study, the increased $\mathrm{N}$ content resulting from three applications of GB resulted in high FF. Although smaller fruit were found for GBtreated 'Regina' cherries, GB applied once at pit hardening did not cause a significantly higher $\mathrm{N}$ level in either cultivar. Therefore, another possibility is that the high $\mathrm{N}$ content of fruit might result from GB residues; the GB molecule includes one $\mathrm{N}$ atom. Therefore, multiple applications of GB allowed more GB into the fruit. However, this hypothesis requires further investigation.

Our previous study demonstrated that an increase in the $\mathrm{Ca}$ content in fruit tissue contributed to firmer cherries (Dong et al., 2019). Interestingly, a significantly higher $\mathrm{Ca}$ content was observed in GB-treated 'Regina' cherries, which may have resulted in in- creased FF. It may be that adding exogenous $\mathrm{Ca}$ to the GB spray protocol increased the weight of cherries, although no change was found in FF (Correia et al., 2019). Additionally, it is unclear whether $\mathrm{Ca}$ sprays could increase the small fruit size of GB-treated 'Regina' cherries.

\section{Conclusion}

Preharvest GB applications enhanced fruit quality and reduced the incidence of disorders for 'Lapins' and 'Regina' cherries more than postharvest applications. The efficacy of preharvest GB spraying for improving cherry quality and storability varied by cultivar and application concentration, frequency, and timing. This study found that the optimum application concentration, frequency, and timing for preharvest GB applications to 'Lapins' or 'Regina' cherries were three applications of $4 \mathrm{~g} \cdot \mathrm{L}^{-1}$ at pit hardening, straw color, and $1 \mathrm{WBH}$. This protocol effectively maintained relatively high FF, TA, and total $\mathrm{N}$ content, as well as reduced the rates of peduncle browning, pitting, and decay during 4 weeks of storage at $0{ }^{\circ} \mathrm{C}$. Although GB sprays caused a relative reduction in the fruit size and an increase in $\mathrm{Ca}$ accumulation in 'Regina', the preharvest application of GB may have the potential to improve quality and disorder tolerance of 'Lapins' and 'Regina' cherries.

Awad, M.A., A.D. Al-Qurashi, and S.A. Mohamed. 2015. Postharvest trans-resveratrol and glycine betaine treatments affect quality, antioxidant capacity, antioxidant compounds and enzymes activities of 'El-Bayadi' table grapes after storage and shelf life. Scientia Hort. 197:350-356.

Clayton, M., W.V. Biasi, I.T. Agar, S.M. Southwick, and E.J. Mitcham. 2003. Postharvest quality of 'Bing' cherries following preharvest treatment with hydrogen cyanamide, calcium ammonium nitrate, or gibberellic acid. HortScience 38:407-411.

Coombe, B.G. 1976. The development of fleshy fruits. Annu. Rev. Plant Physiol. 27:207-228. Gonçalves. 2017. Factors affecting quality and health promoting compounds during

\section{Literature Cited}

Correia, S., R. Schouten, A.P. Silva, and B. growth and postharvest life of sweet cherry (Prunus avium L.). Front. Plant Sci. 8:2166.

Correia, S., F. Queirós, C. Ribeiro, A. Vilela, A. Aires, A.I. Barros, R. Schouten, A.P. Silva, and B. Gonçalves. 2019. Effects of calcium and growth regulators on sweet cherry (Prunus avium L.) quality and sensory attributes at harvest. Scientia Hort. 248:231-240.

Crisosto, C.H., D. Garner, J. Doyle, and K.R. Day. 1993. Relationship between fruit respiration, bruising susceptibility, and temperature in sweet cherries. HortScience 28:132-135.

Crisosto, C.H., G.M. Crisosto, and P. Metheney. 2003. Consumer acceptance of 'Brooks' and 'Bing' cherries is mainly dependent on fruit SSC and visual skin color. Postharvest Biol. Technol. 28:159-167.

Dong, Y., H. Zhi, and Y. Wang. 2019. Cooperative effects of preharvest calcium and gibberellic acid on tissue calcium content, quality attributes, and in relation to postharvest disorders of late-maturing sweet cherry. Scientia Hort. 246:123-128.

Drake, S.R. and D.C. Elfving. 2002. Indicators of maturity and storage quality of 'Lapins' sweet cherry. HortTechnology 12:687-690.

Edin, M., A. Garcin, J. Lichou, and J.M. Jourdain. 1993. Influence of dwarfing cherry rootstocks on fruit production. Acta Hort. 410:239-246.

Fils-Lycaon, B. and M. Buret. 1990. Loss of firmness and changes in pectic fractions during ripening and overripening of sweet cherry. HortScience 25:777-778.

Hansen, M. 2010. Searching for cherry cracking strategies. Good Fruit Grower 61:16-18.

Ingalsbe, D.W., G.H. Carter, and A.M. Neubert. 1965. Fruit pigment measurement, anthocyanin pigments as a maturity index for processing dark sweet cherries and purple plums. J. Agr. Food Chem. 13:580-584

Kappel, F., B. Fisher-Fleming, and E. Hogue. 1996. Fruit characteristics and sensory attributes of an ideal sweet cherry. HortScience 31:443-446.

Lahdenperä, M.L. 2006. Greenstim/Bluestim in suppression of fruit cracking on sweet cherry. $<$ http://verdera.fi/index.php/download_file/view/ 304/204/>

Liu, J., M. Wisniewski, S. Droby, S. Vero, S. Tian, and V. Hershkovitz. 2011. Glycine betaine improves oxidative stress tolerance and biocontrol efficacy of the antagonistic yeast Cystofilobasidium infirmominiatum. Intl. J. Food Microbiol. 146:76-83.

Luo, H., S. Dai, J. Ren, C. Zhang, Y. Ding, Z. Li, Y. Sun, K. Ji, Y. Wang, Q. Li, and P. Chen. 2014. The role of $\mathrm{ABA}$ in the maturation and postharvest life of a nonclimacteric sweet cherry fruit. J. Plant Growth Regul. 33:373-383.

Marschner, H. 1995. Mineral Nutrition of Higher Plants, 2nd ed. Academic Press, London.

Neilsen, G., F. Kappel, and D. Neilsen. 2007. Fertigation and crop load affect yield, nutrition, and fruit quality of 'Lapins' sweet cherry on Gisela 5 rootstock. HortScience 42:1456-1462.

Ragab, M.E., N.A. Helal, O.M. Sawan, Z.F. Fawzy, and S.M. El-Sawy. 2015. Foliar application of glycine betaine for alleviating water stress of tomato plants grown under sandy soil conditions. Intl. J. Chemtech Res. 8:52-67.

Razavi, F., R. Mahmoudi, V. Rabiei, M.S. Aghdam, and A. Soleimani. 2018. Glycine betaine treatment attenuates chilling injury and maintains nutritional quality of hawthorn fruit during storage at low temperature. Scientia Hort. 233:188-194.

Rodríguez-Zapata, L.C., F.L.E. y Gil, S. CruzMartínez, C.R. Talavera-May, F. ContrerasMarin, G. Fuentes, E. Sauri-Duch, and J.M. 
Santamaría. 2015. Preharvest foliar applications of glycine-betaine protects banana fruits from chilling injury during the postharvest stage. Chem. Biol. Technol. Agr. 2:8.

Romano, G.S., E.D. Cittadini, B. Pugh, and R. Schouten. 2006. Sweet cherry quality in the horticultural production chain. Stewart Postharvest Rev. 6:1-8.

Serrano, M., H.M. Diìaz-Mula, P.J. Zapata, S. Castillo, F. Guilleìn, D. Martiìnez-Romero, J.M. Valverde, and D. Valero. 2009. Maturity stage at harvest determines the fruit quality and antioxidant potential after storage of sweet cherry cultivars. J. Agr. Food Chem. 57: 3240-3246.

Shan, T.M., Y.J. Sun, P. Jin, J. Xu, and Y.H. Zheng. 2015. Effects of glycine betaine on loquat fruit quality during cold storage. Acta Hort. 1092: 131-137.

Shan, T.M., P. Jin, Y. Zhang, Y.P. Huang, X.L. Wang, and Y.H. Zheng. 2016. Exogenous glycine betaine treatment enhances chilling tolerance of peach fruit during cold storage. Postharvest Biol. Technol. 114:104-110.

Swarts, N.D., E. Mertes, and D.C. Close. 2017. Role of nitrogen fertigation in sweet cherry fruit quality and consumer perception of quality: At-and postharvest. Acta Hort. 1161:503-510.

Toivonen, P.M.A., F. Kappel, S. Stan, D.L. McKenzie, and R. Hocking. 2004. Firmness, respiration, and weight loss of 'Bing', 'Lapins' and 'Sweetheart' cherries in relation to fruit maturity and susceptibility to surface pitting. HortScience 39:1066-1069.

Tukey, H.B. 1936. Development of cherry and peach fruits as affected by destruction of the embryo. Bot. Gaz. 98:1-24.

Tukey, H.B. and J.O. Young. 1939. Histological study of the developing fruit of the sour cherry. Bot. Gaz. 100:723-749.

Turner, J., C. Seavert, A. Colonna, and L.E. Long. 2005. Consumer sensory evaluation of sweet cherry cultivars in Oregon, USA. Acta Hort. 795:781-786.

Valero, D., H.M. Díaz-Mula, P.J. Zapata, S. Castillo, F. Guilleìn, D. Martínez-Romero, and M. Serrano. 2011. Postharvest treatments with salicylic acid acetylsalicylic acid or oxalic acid delayed ripening and enhanced bioactive compounds and antioxidant capacity in sweet cherry. J. Agr. Food Chem. 59:5483-5489.

Warner, G. 2013. Reluctant Regina. Good Fruit Grower 64:28-29.
Wang, Y., X. Xie, and L.E. Long. 2014. The effect of postharvest calcium application in hydro-cooling water on tissue calcium content, biochemical changes, and quality attributes of sweet cherry fruit. Food Chem. 160:22-30.

Whiting, M.D. and G.A. Lang. 2004. Bing sweet cherry on the dwarfing rootstock Gisela 5: Crop load affects fruit quality and vegetative growth but not net $\mathrm{CO}_{2}$ exchange. J. Amer. Soc. Hort. Sci. 129:407-415.

Whiting, M.D. and D. Ophardt. 2005. Comparing novel sweet cherry crop load management strategies. HortScience 40:1271-1275.

Zhang, C. and M. Whiting. 2013. Plant growth regulators improve sweet cherry fruit quality without reducing endocarp growth. Scientia Hort. 150:73-79.

Zheng, X., C. Yue, K. Gallardo, V. McCracken, J. Luby, and J. McFerson. 2016. What attributes are consumers looking for in sweet cherries? Evidence from choice experiments. Agr. Resour. Econ. Rev. 45:124-142.

Zhi, H. and Y. Dong. 2018. Effect of hydrogen sulfide on surface pitting and related cell wall metabolism in sweet cherry during cold storage. J. Appl. Bot. Food Qual. 91:109-113. 
Supplemental Table 1. Meteorological data from 2016, 2017, and 2018.

\begin{tabular}{llcccc}
\hline Yr & Month & Mean temp $\left({ }^{\circ} \mathrm{C}\right)$ & Mean humidity $(\%)$ & Mean wind $\left(\mathrm{m} \cdot \mathrm{s}^{-1}\right)$ & Precipitation $(\mathrm{mm})$ \\
\hline 2016 & April & 13.9 & 59 & 1.30 & 1.47 \\
& May & 16.1 & 57 & 1.61 & 2.4 \\
& June & 18.9 & 57 & 2.23 & 1.3 \\
2017 & July & 20.6 & 57 & 1.89 & 1.39 \\
& April & 9.4 & 70 & 1.74 & 0 \\
& May & 15.6 & 60 & 2.37 & 0 \\
2018 & June & 18.9 & 57 & 1.07 & 0 \\
& July & 22.8 & 49 & 2.10 & 0 \\
& April & 11.1 & 56 & 1.88 & 0.3 \\
& May & 17.2 & 54 & 1.74 \\
\hline
\end{tabular}

